\title{
Transition Zone-Like
}

National Cancer Institute

\section{Source}

National Cancer Institute. Transition Zone-Like. NCI Thesaurus. Code C113735.

A morphologic finding indicating the presence of an epithelial infiltrate resembling the cells of the transition zone of the prostate gland. 